University for Business and Technology in Kosovo

UBT Knowledge Center

UBT International Conference

2012 UBT International Conference

Nov 2nd, 9:00 AM - Nov 3rd, 5:00 PM

\title{
Nature in Architecture - Japan Architecture, Lessons for Kosovo
}

Arta Jakupi

Bauhaus University of Weimar

Follow this and additional works at: https://knowledgecenter.ubt-uni.net/conference

Part of the Architecture Commons

\section{Recommended Citation}

Jakupi, Arta, "Nature in Architecture - Japan Architecture, Lessons for Kosovo" (2012). UBT International Conference. 26.

https://knowledgecenter.ubt-uni.net/conference/2012/all-events/26

This Event is brought to you for free and open access by the Publication and Journals at UBT Knowledge Center. It has been accepted for inclusion in UBT International Conference by an authorized administrator of UBT Knowledge Center. For more information, please contact knowledge.center@ubt-uni.net. 


\title{
Nature in Architecture - Japan Architecture, Lessons for Kosovo
}

\author{
Arta Jakupi- architect, $\mathrm{PhD}$ candidate ${ }^{1}$ \\ ${ }^{1}$ Bauhaus University of Weimar
}

Abstract: Focus of my research is to be found on several issues concerning architectural opinions and design in Japan, and for better understanding of its development the attention will be set from the old toward the current architectural endeavors.

The created urban mess of Kosovo, beside it's over built and overcrowded area lacks the most valuable quality of a living settlement- its greenery. The suffocation of the living area can be reduced by producing; inventing; reusing more greenery, more gardens with its calming and meditative effect. The research study reveals a solution; hidden on the inclusiveness of nature into the built architecture; the architecture can be opened and integrated into its environment, same as in Japan Architecture where the surrounding garden is regarded as a necessary supplement to the building. Japanese Garden does not exist as an independent entity, building is directly related to its natural surrounding and that is one of the most powerful attributes of the Japanese architecture.

Knowing the effect that the surrounding has on the psychology of the inhabitants, the manner of the Japan design by enhancing the inside living environment from the outside would produce more simple and practical solution, which could also be manifested on the culture of behavior.

The application of the Qualitative Methodologywas considered to be most applicable for the study under research as well as the time length available. The tools for data gathering were observation; photos; documents; informal interviews; methodology of the research includes also a lot of fieldwork (Kyoto, Nara, Osaka, Tokyo) as an opportunity to analyze and experience firsthand the nature into the Old and New Japanese Architecture (temples, palaces, shrine, residential and modern buildings) consequently complemented by literature available at the Kyoto Seika University Library, Kyoto University Library and other online resources. The qualitative analyze of the data was done by applying an "interpretive" approach which is phenomenological in nature and seeks to present data more in a holistic manner.

During my investigation I have encountered many situations which as fragmented were very similar to Kosovo, but when considered as a whole it would change the perspective. The design features and Japan built assets can generate a whole new theory from which Kosovo can benefit.

The design features which were present in most of the cities that I have visited were dealing with patchwork against network; fluid rather than fixed; transformation and alteration; co-existence of different parts; features upon which the same theory could be erected in Kosovo.

Key Words: Architecture, Nature, Kosovo, Japan, Garden 